\title{
Functional Evaluation of Proximal Humerus Fracture Managed by Locking Plate
}

\section{Yogesh Savliram Gangurde ${ }^{1}$, Neetin Pralhad Mahajan ${ }^{1}$, Dhiraj Vithal Sonawane}

${ }^{1}$ Grant Medical College And Sir J.J.Group Of Hospitals Mumbai, India

Institute at which research was conducted: Grant Medical College And Sir J.J.Group Of Hospitals Mumbai, India

University Affiliation of Thesis: Maharashtra University of Health Sciences

Year of Acceptance: 2012

Address of Correspondence

Dr. Yogesh Savliram Gangurde

Dept. Of Orthopaedics, Sir J.J. Group Of Hospital, 2nd Floor Main Building. Mumbai, Maharashtra, India.

E mail:dryogeshg18@gmail.com

Abstract: Background: Our study is planned to evaluate functional evaluation of proximal humeral fractures treated with open reduction and internal fixation with locking plates in view of range of movement, possible returns of basic functions around shoulder girdle, radiological outcome and resultant remaining disability in the course of healing and after completion of healing.

Materials and methods: Over two and half years 35 patients with proximal humerus fractures were managed With locking plate 34 of them completed mean follow up 11 months and evaluated using SPADI score.

Result: Average SPADI score for different fracture type according to Neers classification were suggestive of there is no statistically significant difference between these fracture types managed with locking plate. We found approximately equal Mean SPADI score in all 2 part, 3 part and 4 part fractures. Overall functional outcome found to be moderate to good in $92 \%$ of our patient but $8 \%$ patient had poor outcome due to associated complications postoperatively.

Conclusion: Proximal humeral locking plate is an exciting new method of osteosynthesis for complex proximal humerus fractures allowing early mobilization, good functional outcome and is a superior treatment option to hemiarthoplasty.

Keywords: Proximal humerus locking plate, SPADI score.

\section{THESIS SUMMARY}

\section{Introduction:}

Fractures of the proximal humerus are representing no more than $3 \%$ of all upper extremity fractures and approximately $4 \%$ to $5 \%$ of all fractures. 1

Three fourths of the fractures occur in older individuals with an occurrence three times more often in women than in men .

Severely displaced and comminuted fractures warrant surgical management for optimum shoulder function.

Traditional surgical treatment methods include percutaneous or minimally invasive techniques such as pinning, osteosynthesis fixation. using cancellous screws, open reduction and internal fixation with proximal humeral plates, and the use of intramedullary nails, hemiarthroplasty .

Various complications associated with above methods are implant failure, loss of reduction, non-union or malunion of the fracture, impingement syndrome, and osteonecrosis of the humeral head.

The key to this technology is fixed angle relationship between the screws and plate.

Even biomechanical analysis studies have showed the superiority of such locking Over two and half years 35 patients with 
proximal humerus fractures were managed All patients with age between 20 and 60 years and Closed two part post traumatic fracture with major Humeral diaphyseal displacement or three or four part fracture with tuberosity displacement enough to cause significant subacromial impingement were included.they were treated with with locking plate. Patients were evaluated on OPD basis at 6 weeks, 12 weeks, 6 months and 1 year follow up visit standard AP and axillary radiographs were obtained and All radiographs were evaluated for fracture healing, implant related problems- screw perforation, screw loosening or backing out, plate pullout or breakage, anatomical alignment- major varus or valgus and evidence of postoperative osteonecrosis. Functional outcome was assessed using Shoulder Pain And Disability Index (SPADI) score at each follow up done at 6 week, 3 month. 6 month and 1 year

34 of them completed mean followup 11 months and evaluated using SPADI score. The statistical analysis was done using SPSS 17 th Edition.

Results:

All fractures united with average time taken for union was approximately 3 months.

Average SPADI score for different fracture type according to Neers classification were suggestive of there is no statistically significant difference between these fracture types managed with locking plate.

On comparison with respect to age distribution patients in 6 th decade shows comparatively low functional outcome as compare to lower age group.

In four patients we have found complications which are screw penetration, impingement, implant failure and infection. We found approximately equal Mean SPADI score in all 2 part, 3 part, 4 part fractures. But Mean SPADI score in 6 th decade is on higher side as compare to $3 \mathrm{rd}$, 4 th, 5 th decade.

overall functional outcome found to be moderate to $\operatorname{good}$ in $92 \%$ of our patient but $8 \%$ patient had poor outcome due to associated complications postoperatively.

\section{Conclusion:}

We believe that a reproducible standard surgical technique is necessary for improved patient outcome..Proximal humeral locking plate is an exciting new method of osteosynthesis for complex proximal humerus fractures allowing early mobilization, good functional outcome and is a superior treatment option to hemiarthoplasty.

Key Words:

Proximal humerus locking plate, SPADI score.

\section{Bibliography}

1. J. M. Muthuuri Outcome Of Plate Osteosynthesis In The Management Of Proximal Humeral Fractures In Adults. East African Orthopaedic Journal, September 2010 Vol. 4:37-40.

2. Ralph Hertel Lindenhofspital, Berne, Fractures of the proximal humerus in osteoporotic bone Osteoporos Int. 2005 Mar;16
Suppl 2:S65-72. Epub 2004 Oct30.

3. Szyszkowitz R, Seggl W, Schleifer P, et al Proximal humeral fractures Management techniques and expected results Clin Orthop 1993 SZYSZKOWITZ.

4. Nho SJ, Brophy RH, Barker JU, Cornell CN, MacGillivray JD. Innovations in the management of displaced proximal humerus fractures. J Am Acad Orthop Surg. 2007;15(1):12-26.

5. Wijgman AJ, Roolker W, Patt TW, Open reduction and internal fixation of three and four-part fractures of the proximal part of the humerus J Bone Joint Surg Am 2002 01;84(11):19191925.

6. Gerber $C$, Werner CM, Vienne P Internal fixation of complex fractures of the proximal humerus. J Bone Joint Surg Br. 2004 Aug,848-55. Department of Orthopaedics, University of Zürich, Balgrist, Switzerland.

7. Esser RD. Open reduction and internal fixation of three- and four-part fractures of the proximal humerus. Clin Orthop Relat Res. 1994 Feb;(299):244-51.

8. Paavolainen P, Björkenheim JM, Slätis P, Paukku P. Operative treatment of severe proximal humeral fractures. Acta Orthop Scand. 1983 Jun;54(3):374-9.

9. Aggarwal S, Bali K, Dhillon MS, Kumar V, Mootha AK Displaced proximal humeral fractures: an Indian experience with locking plates J Orthop Surg Res. 2010 5:60.

10. Südkamp N, Bayer J, Hepp P, et al Open reduction and internal fixation of proximal humeral fractures with use of the locking proximal humerus plate. Results of a prospective, multicenter, observational study. J Bone Joint Surg Am 2009 01;91(6):1320-1328.

11. Fankhauser F, Boldin C, Schippinger G, Haunschmid C, Szyszkowitz $R$ A new locking plate for unstable fractures of the proximal humerus. Clin Orthop Relat Res. 2005 Jan;(430):17681.

12. Koukakis A, Apostolou CD, Taneja T, Korres DS, Amini A. Fixation of proximal humerus fractures using the PHILOS plate: early experience. Clin Orthop Relat Res. 2006 Jan;442:115-20.

13. Kettler M, Biberthaler P, Braunstein V, Zeiler C, Kroetz M, Mutschler $W$. Treatment of proximal humeral fractures with the PHILOS angular stable plate. Presentation of 225 cases of dislocated fractures. Unfallchirurg. 2006 Dec;109(12):1032-40.

14. Bigorre N, Talha A, Cronier P, Hubert L, Toulemonde JL, Massin P. A prospective study of a new locking plate for proximal humeral fracture. Injury. 2009 Feb;40(2):192-6. Epub 2008 Dec 13.

15. G.G.KONRAD, A.MEHLHORN, J.KÜHLE,P.C.STROHM, N. P SÜDKAMP Klinikum der Alber Proximal Humerus 
Fractures - Current Treatment Options $t$-Ludwigs-Universität Freiburg,Germany 2006 ACTA CHIRURGIAE ORTHOPAEDICAE ET TRAUMATOLOGIAE ČECHOSL., 75, 2008, p. $413-421$.

16. Antuña SA, Sperling JW, Cofield RH Shoulder hemiarthroplasty for acute fractures of the proximal humerus: $a$ minimum five-year follow-up. J Shoulder Elbow Surg. 2008 MarApr;17(2):202-9. Epub 2008 Jan 11.

17. Dietrich M, Meier C, Lattmann T, Zingg U, Grüninger P, Platz A. Complex fracture of the proximal humerus in the elderly. Locking plate osteosynthesis vs hemiarthroplasty Chirurg. 2008 Mar;79(3):231-40.

18. Solberg BD, Moon CN, Franco DP, Paiement GD Surgical treatment of three and four-part proximal humeral fractures. $J$ Bone Joint Surg Am. 2009;91(7):1689-1697

19. Handschin AE, Cardell M, Contaldo C, Trentz O, Wanner GA. Functional results of angular-stable plate fixation in displaced proximal humeral fractures.Injury. 2008 Injury:;39(3):306-13

20. Krivohlavek M,Lukas R,Tallers Sram $j$ Use of angle-stable implants for proximal humeral fractures: prospective study. J Bone Joint Surg Br. 2004 Aug;86(6):848-55. Acta Chir Orthop Traumatol Cech. 2008 Jun;75(3):212-20.

21. Michael Leonard, Leibo Mokotedi, Uthman Alao, Aaron Glynn, Mark Dolan, and Pat Fleming. The use of locking plates in proximal humeral fractures: Comparison of outcome by patient age and fracture pattern INT J SHOULDER SURG. 2009 OCT-DEC; 3(4): 85-89.

mailto:mikeleonard77@gmail.com.

22. Chu SP, Kelsey JL, Keegan TH, et al.: Risk Factors For Proximal Humerus Fracture. Am J Epidemiol 2004, 15(160):360-367.

23. Lind T, Krøner K, Jensen J. The epidemiology of fractures of the proximal humerus. Arch Orthop Trauma Surg. 1989;108(5):285-7.

24. Neer CS: Displaced proximal humeral fractures-II. Treatment of three-part and four-part displacement JBone Joint Surg Am 1970, 52(6):1090-103.

25. Charles Neer (1970) Displaced proximal humeral fractures. Classification and evaluation. : J Bone Joint Surg Am 1970, 52:1077-1089.

26. Meier RA, Messmer P, Regazzoni P, Rothfischer W, Gross T. Unexpected high complication rate following internal fixation of unstable proximal humerus fractures with an angled blade plate. JOrthop Trauma. 2006 Apr;20(4):253-60.

27. Paul C. Siffri, Richard D. Peindl, Edward R. Coley, James Norton, Patrick M. Connor and James F. Kellam Biomechanical
Analysis of Blade Plate Versus Locking Plate Fixation for a Proximal Humerus Fracture: Comparison Using Cadaveric and Synthetic Humeri J Orthop Trauma 2006;20:547-554.

28. Dr.k kodandapani. Proximal humerus fracture Management - Presentation Transcript 2012 ;page 2.

29. B. R. Singer, G. J. McLauchlan, C. M. Robinson, J. Christi, The influence of age and gender. Epidemiology of fractures in 15000 adults J Bone Joint Surg [Br] 1998;80-B:243.

30. Kwon YW, Zuckerman JD Outcome after treatment of proximal humeral fractures with humeral head replacement. 30 2005 Instr Course Lect. 2005;54:363-9.

31. Kim SH, Lee YH, Chung SW, Shin SH, Jang WY, Gong HS, Baek GH Outcomes for four-part proximal humerus fractures treated with a locking compression plate and an autologous iliac bone impaction graft. Injury 2012 Oct;43(10):1724-31.

32. Michael J. Gardner, MD, Yoram Weil, MD, Joseph U. Barker, MD, Bryan T. Kelly, MD, David L. Helfet, G. Lorich, The Importance of Medial Support in Locked Plating of Proximal Humerus Fractures JOrthop Trauma 2007;21:185-191.

33. Plecko $M$, Kraus A. Internal fixation of proximal humerus fractures using the locking proximal humerus plate .Oper. Orthop. Traumatol 2005; 17:25-50.

34. Shahid R, Mushtaq A, Northover J, Maqsood M Outcome of proximal humerus fractures treated by PHILOS plate internal fixation. Experience of a district general hospital. Acta Orthop Belg. 2008 Oct; 74(5):602-8.

35. Kevin C Owsley,John J. Goczyca Displacement and screw cutout after open reduction and locked plate fixation of proximal humerus fracture. J Bone Joint Surg Am, 2008 Feb 01;90(2):225225.

36. Ricardo Souza e Silva Morelli; Rodrigo Eisler de Souza Travizanuto Proximal humerus fractures: comparative study of two different fixation methods. Acta ortop. Bras. Vol.18 no. 2 são paulo 2010 Department of Orthopedics and Traumatology of Hospital Vera Cruz de Campinas. SP. Brazil

37. Norouzi M, Naderi MN, Komasi MH, Sharifzadeh SR, Shahrezaei M, Eajazi A. Clinical results of using the proximal humeral internal locking system plate for internal fixation of displaced proximal humeral fractures. Am J Orthop (Belle Mead NJ). 2012 May;41(5):E64-8.

38. Ruchholtz S, Hauk C, Lewan U, Franz D, Kühne C, Zettl R. Minimally invasive polyaxial locking plate fixation of proximal humeral fractures: a prospective study. J Trauma. 2011 Dec;71(6):1737-44.

39. Crispin C. Ong, MD, Young W. Kwon, MD, PhD, Michael Walsh, PhD, Roy Davidovitch, MD, Joseph D. Zuckerman, MD, 
and Kenneth A. Egol, MD Outcomes of Open Reduction and Internal Fixation of Proximal Humerus Fractures Managed With Locking Plates. Am JOrthop. 2012;41(9):407-412.

40. Haidukewych GJ. Innovations in locking plate technology. J Am Acad Orthop Surg. 2004;12(4):205-212.

41. Juan Agudelo, MD, Matthias Schu"rmann, MD, Philip Stahel, $M D$, Peter Helwig, MD, $\$$ Steven J. Morgan, MD,Wolfgang Zechel, MD, Christian Bahrs, MD, \$ Anand Parekh, Bruce Ziran, $M D$, Allison Williams, $N D, P h D$, and Wade Smith, $M D^{*}$ Analysis of Efficacy and Failure in Proximal Humerus Fractures Treated With Locking Plates. J Orthop Trauma 2007;21:676-681.

42. SEHR JR Szabo RM Semitubular blade plate for fixation in proximal humerus fracture. Journal of ortho. trauma 1988;2(4):327-32.

43. Eric J. Strauss Current status of locking plate .The good, bad,ugly. Journal of ortho. trauma,2008,22,479, 486.

44. Felix Brunner,Christopher sommer,Rainer Heuwinkled, George Kohut Open reduction and internal fixation of proximal humerus fractures using a proximal humerus locked plate; A prospective multicenter analysis Journal of ortho. trauma 2009,23,163-172.

45. Geiger Ev, Maier M, Kelm A, WutzlerS, Seebach C, Marzi I. Functional outcome and complications following proximal humerus interlocking system plate fixation in proximal humerus fracture. Acta orthopaedic traumatol turc 2010;44(1):1-6.

46. Duralde XA, Leddy LR. The results of ORIF of displaced unstable proximal humeral fractures using a locking plate. $J$ Shoulder Elbow. Surg 2010;19:480-8.

47. Clavert P, Adam P, Bevort A, Bonnomet F, Kempf JF Pitfalls and complications with locking plate for proximal humerus fracture. Ricchetti ET, Warrender WJ, Abboud JA. Use of locking plates in the reatment of proximal humerus fractures. J Shoulder Elbow Surg. 2010 Mar;19(2 Suppl):66-75.

48. Olerud P, Ahrengart L, Söderqvist A, Saving J, Tidermark J.Quality Of Life And Functional Outcome After A 2-Part Proximal Humeral Fracture: A Prospective Cohort Study On 50 Patients Treated With A Locking Plate. J Shoulder Elbow Surg. 2010Sep;19(6):814-22.

49. Parmaksizoğlu AS, Sökücü S, Ozkaya U, Kabukçuoğlu Y, Gül $M$ Locking plate fixation of three- and four-part proximal humeral fractures. Acta Orthop Traumatol Turc. 2010;44(2):97104.

50. Yang H, Li Z, Zhou F, Wang D, Zhong B. A Prospective Clinical Study of Proximal Humerus Fractures Treated with A Locking Proximal Humerus Plate. J Orthop Trauma. 2011 Jan;25(1):117.

51. Zhang L, Zheng J, Wang W, Lin G, Huang Y, Zheng J, Edem Prince A, Yang G. The clinical benefit of medial support screws in locking plating of proximal humerus fractures: a prospective randomized study. Int Orthop. 2011 Nov;35(11):1655-61.

54. Burke NG, Kennedy J, Green C, Dodds MK, Mullett H. Spross C, Platz A, Rufibach K, Lattmann T, Forberger J, Dietrich $M$ The PHILOS plate for proximal humeral fractures--risk factors for complications at one year. J Trauma Acute Care Surg. 2012 Mar;72(3):783-92.
Conflict of Interest: Nil

Source of Support: None
Full Thesis and Master Chart available on www.journalmedicalthesis.com

How to Cite this Article:

Gangurde YS, Mahajan NP, Sonawane DV. Functional Evaluation of Proximal Humerus Fracture Managed by Locking Plate. Journal Medical Thesis 2013 July-Sep; 1(1):29-32 